\title{
Anna Bistroń \\ Jagiellonian University \\ THE IDENTITY OF \\ A ROMANIAN-ISRAELI \\ WRITER IN LIGHT \\ OF TRANSCULTURAL \\ THEORY: THE CASE OF \\ VIRGIL DUDA
}

\author{
The Identity of a Romanian-Israeli Writer in Light of Transcultural Theory: The Case of Virgil \\ Duda
}

\begin{abstract}
The article at hand comprises an attempt to answer the question about the identity of Virgil Duda, a recognized and respected in literary circles Romanian writer, who, as an almost 50-year-old artist, decided to leave (together with his family) for Israel - a country whose language and culture were completely foreign to him. These will not be deliberations on the subject of national identity. From amidst many a research field associated with the subject of identity, I have selected cultural space and it is from this perspective that I will look at Virgil Duda and his Israeli-period writing. In the case of this RomanianJewish-Israeli artist justified is a rendering of the concepts of cultural character and cultural identity as seen by Wolfgang Welsch and François Jullien.
\end{abstract}

KEY WORDS: Identity, Romanian-Israeli writer, Virgil Duda, citizen of the world

To be a Pole is already a misfortune. To be a Pole and a Jew is misfortune doubled.

To be a Pole, a Jew, and a writer -

That is misfortune tripled. ${ }^{1}$

The above-cited lament by Kazimierz Brandys regarding the identity of a JewishPolish Artist could just as easily be applied to the case of a Romanian Jew, a citizen of Israel, who is also a writer composing his works in Romanian. This sketch is dedicated to precisely such a man - Virgil Duda - a Jew and recognized Romanian writer who, as a mature adult, made the decision to emigrate to Israel.

1 As cited in: E. Prokop-Janiec, “Żyd - Polak - artysta: o budowaniu tożsamości po Zagładzie,” Teksty Drugie, nr 1 (66), 2001, pp. 120-134. 
Virgil Duda was born in 1939 as Rubin Leibovici, the child of a Jewish, rather traditional family in the relatively small town of Bârlad in eastern Romania. Orphaned rather early, he followed in the footsteps of his older brother - Lucian Raicu, who would become a renowned literary critic - and moved to Bucharest. Duda studied law in the capital city, subsequently practicing this profession until 1970. Meanwhile, however, convinced by his brother to do so, Duda wrote and successfully published his first collection of short stories Povestiri din provincie (1967). Two years later, he embarked in earnest on the career path of a novelist with the issuance of Catedrala (1969), and then Anchetatorul apatic (1971).

In 1970 he undertook a position in the filmmaking sector - first as an editor at Studioul Cinematografic [The Cinematographic Studio], and afterwards as a producer in the Casa de Filme [Film Center], both in Bucharest. By the moment of his emigration to Israel, his literary output encompassed ten volumes ${ }^{2}$ which were not only recognized and respected in literary circles, but which also brought him literary honors. ${ }^{3}$ And yet, as an almost 50-year-old writer, whose tool of the trade and instrument of expression was the Romanian language, he decided to leave (together with his wife and teenage daughter) for Israel - a country whose language and culture were completely foreign to him.

During a meeting with the writer in his Tel Aviv apartment, we conversed about his Romanian past, about his parents and family home, about Jewish tradition and antiSemitism, about literature, about the reasons underlying his emigration decision, and, finally, about the Israeli "here and now." When I posed the question, "Who are you?" and requested a brief reply, a long silence ensued before the response was heard: "Above all, a writer." The subsequent discussion touching upon biographic themes - the older, Romanian as well as the current, Israeli - was not as meaningful for me as those seconds of suspense.

The article at hand comprises an attempt to fill in that silence, an attempt to answer the question about the identity of Virgil Duda. Yet these will not be deliberations on the subject of national identity. ${ }^{4}$ From amidst many research fields associated with the subject of identity, I have selected cultural space and it is from this perspective that I will look at Virgil Duda and his Israeli period writing.

In this article, I will not be utilizing the psychological definition of identity, yet it behooves me to mention the basic traits of this source-centered aspect of self-identification. As we read in an article by Anna Brzezińska:

Personal development, from the beginning of a person's life, progresses simultaneously in two contexts - the temporal and the socio-cultural - in a delineated space and time [...]. The

2 In addition to the three already mentioned, seven other books by Virgil Duda had appeared: Deruta (1973); Al doilea pasaj (1975); Cora (1977); Măștile (1979); Războiul amintirilor (1981); Hărţuiala (1984); and Oglinda salvată (1986).

3 Premiul Comitetului Central al Uniunii Tineretului Comunist [Central Committee of the Communist Youth Union Award] (1969); Premiul Asociaţiei Scriitorilor din București [Bucharest Writers Association Award] (1979); Premiul Uniunii Scriitorilor [Writers Union Award] (1981).

4 Among the classic works dealing with this problematic, I am inclined towards the concepts of (among others) Eric Hobsbawm and Benedict Anderson who advocate for a view of the nation as secondary, a category more likely to be defined a posteriori. It would be difficult not to agree that it is a social construct, "imagined" for the purposes of political discourse. This is a realm, however, beyond the purview of my interests and this article. 
socio-cultural context is comprised of all the relationships and interactions, all the groups, organizations, and communities in which the individual participates at a specific period of his or her life. Identity $[\ldots]$ is shaped throughout the entire life of the human being but the periods of the greatest significance are childhood and maturation. It is in childhood that the individual accumulates knowledge about the world and about him or herself [...] (Brzezińska 2006: 47).

The whole of this "baggage" does affect the skill of functioning in a social space. This is the psychological aspect of the concept of identity: a sense of separateness and development in a specific sociocultural context. But if we speak of development, then this implies a change stemming from the impact of various external factors as well as the arbitrary choices of the individual. Zygmunt Bauman writes that, "[...] 'belonging' and 'identity' are not cut in rock, that they are not secured by a lifelong guarantee, that they are eminently negotiable and revocable; and that one's own decisions, the steps one takes, the way one acts - and the determination to stick by all that - are crucial factors of both. In other words, the thought of 'having an identity' will not occur to people as long, as 'belonging' remains their fate, a condition with no alternative (Bauman 2007: 11).

Identity is, therefore, a certain type of task which we must execute autonomously, accepting personal responsibility for the choices we make. Jean-Claude Kaufmann speaks in favor of a concept of identity as a subjective creation by an individual, a concept which is "[...] precisely the opposite of an unalterable, homogenous mass and - quite the contrary - is in constant movement [...]." ${ }^{5}$

The problem of identity, including cultural identity, was, is and will likely forever be a topic of discussions and deliberations by scholars. The wealth of works in this field forces limitations in this presentation to a few, select perspectives on this issue; the path of these deliberations will be demarcated in correspondence (inasmuch as this is possible) with changes currently underway in the sociocultural world. Implementation of the concept of cultural identity, however, does necessitate a brief outline of this viewpoint with regards to the category of culture.

It would certainly be inappropriate to hold onto Johann Herder's definition of culture ${ }^{6}$ in the era of universal, ubiquitous, and expeditious communication (in both a migratory spatial and medial temporal sense). Societies today are neither culturally, nor ethnically uniform, and it would be difficult to clearly delineate intercultural boundaries. The traditional concept of homogeneous cultural "islands" is outdated (the irrepressibility of the "pure" cultures concept in today's general political discourse is a completely different matter).

Hence justified is a rendering of the concepts of cultural character and cultural identity as seen by Wolfgang Welsch and François Jullien. These concepts acknowledge an increased tempo in the mutual interfusion of elements drawn from different cultures, but avoid using terms such as unification or globalization (seen quite negatively today) to describe this phenomenon. Welsch, critiquing the definition of these cultural phenomena

5 This movement is, naturally, coerced or stimulated by both biographical changes (such as emigration), as well as other external contexts which do exert a sort of pressure on the choices made by an individual. See Kaufman 2013: 22).

$619^{\text {th }}$ century theories refer to the homogeneity of ethnic cultures displaying distinct boundaries. In the $20^{\text {th }}$ century, T.S. Eliot (among others) referred to this idea, but in the $21^{\text {st }}$, such a concept is, from an academic standpoint, completely inadequate in describing contemporary cultures. 
via the concepts of multi- or inter-culturalism, ${ }^{7}$ proposes a different idea which recognizes the mixing and mutual permeation of cultures: transculturalism. Welsch describes present-day culture as a global (not globalizing) phenomenon. ${ }^{8}$ What seems especially crucial in Welsch's transculturalism theory is a rejection of "culture" in the context of isolationism and conflict but recognition of a positive value to the intercultural relations which emerge from the mixing of diverse elements found in distinct cultures. This added value disavows unification or globalization, and comprises an enrichment for participants in a culture.

However, the French philosopher, François Jullien does not perceive a threat of cultural unification or globalization. In fact, he controversially asserts that cultural identity does not exist (Jullien 2016). Here one could assume that this signifies the questioning of culture and/or cultural identity perceived as immovable, consistent monoliths. Understood in this sense, a monolith is impossible as both these categories are subject to constant change and negotiation. In fact, the most fundamental trait of culture is its changeability, transformations, and mutations. Only dead cultures (like dead languages) remain unmodified. ${ }^{9}$ According to the French philosopher, the role of participants in a culture is to protect its sources. By protection, Jullien does not mean their "defense," but rather the maintenance and preservation of a culture's elements by way of their exploitation and dissemination as a shared wealth and resource from which any and all can draw who sees something interesting and valuable therein (Jullien 2016: 51-56).

Welsch, in turn, by referring to the "precursors"10 of transculturalism, emphasizes the distinction of the category of cultural identity. In the eyes of this German philosopher there is no way it can be associated with national identity: "The insinuation that someone who possesses an Indian or a German passport must also culturally unequivocally be an Indian or a German [...] is as foolish as it is dangerous. The detachment of civic from personal or cultural identity is to be insisted upon - all the more so in states [...] in which freedom in cultural formation belongs among one's basic rights" (Welsch 1998: 209). It is hard not to notice that a good illustration of the above-cited claim are precisely the transcultural traits of the participants in Israeli society (even when perusing solely

Both the multiculturalism and interculturalism concepts continue to assume some level of cultural uniformity and cultural isolation concurrent in a given nation-state. The softening of such ideas and their application in political practice do promote mutual tolerance, but this is a form of "positive thinking" which does not prove itself true in crisis situations. See Welsch 1998: 194-213.

8 The term "globalization" has become a bit of a synonym for unification which directly contradicts the theory of transculturalism. The intertwining and choosing of cultural elements do not lead to the homogenization of cultures because each person will reach for a different combination of elements, creating a separate individual identity on the one hand, and preserving those sociocultural elements on the other.

9 See the response by Jullien in an interview conducted by Anastasia Vecrin (30 ${ }^{\text {th }}$ September 2016) http://www.liberation.fr/debats/2016/09/30/francois-jullien-une-culture-n-a-pas-d-identite-car-elle-ne-cessede-se-transformer_1516219 (last accessed: 28 $8^{\text {th }}$ June 2017): “Quand je dis 'il n'y a pas d'identité culturelle', ce n'est pas une provocation. Une culture n'a pas d'identité pour une raison élémentaire: c'est qu'elle ne cesse de se transformer. Comme c'est le cas pour les langues: quand une culture, une langue, ne se transforme plus, elle est morte." ["When I say that 'cultural identity does not exist,' this is not a provocation. Culture does not have an identity for one basic reason: culture does not stop changing. It is the same with languages: if a culture or a language ceases to change, then it is dead."]

10 Welsch refers to such thinkers as Montaigne, Rimbaud, Nietzsche, Whitman, Novalis, and others. See Welsch 1998: 192-222. 
the Jewish component). This is something that stands in obvious opposition to the "nationalistic" political discourse of that state. ${ }^{11}$

It is precisely the context of cultural identity, underpinned by the theory of transculturalism, which will serve as the backdrop for an enquiry into select texts penned by the writer, Virgil Duda. The specific material to be analyzed (limited for obvious reasons) are the books this writer penned in his new fatherland, in Israel.

Who is Rubin Leibovici? Is he a Romanian, a Jew, an Israeli, or perhaps a "citizen of the world" who cuts himself off from the possibility of being slipped into the drawer of a single cultural identity? Reading his "Israeli period" prose, one gets the impression that a geographical-cultural distancing from a "space" (in a very general sense) spotlighted a need to analyze his own cultural identity; it is only at the wellspring of a reshaped individual identity that this author posed questions of his cultural self-identification, or lack thereof. The Israeli chapter of Virgil Duda's writings reflects, in some way, a need to conceptualize his own identity. With a great degree of certainty, one can claim that this process was enhanced by crucial elements in the writer's biography: breakups, turnarounds, returns, disappointments, as well as the influence of both the old and new political discourses in Romania and Israel.

The transcultural nature of the identity of Virgil Duda is a problem little explored signaled only occasionally, somewhere between the lines in a handful of texts about Duda's work. ${ }^{12}$ Useful in seeking answers to questions raised hereby will be the category of narrative identity, a concept borrowed from the realm of philosophy and anthropology. The concept of narration, key to Ricœur's philosophy of identity ${ }_{13}^{13}$ can be counted as a cognitive category because it is precisely through narration (a "story" about oneself in action) that we come to know both reality and (especially) ourselves. As Eliza Karczyńska put it in her article (Karczyńska 2014: 65-76) narration's task is to organize our experiences, our way of looking at reality, and our understanding of ourselves. In narration it is as if we are presenting ourselves to ourselves, all the while looking at ourselves in the mirror which is the "Other." Reactions and relationships with the everchanging "Other" - alongside a culturally and geographically ever-changing space means that a person's identity comprises a never completed project. A tale of who I was, who I am, and who I want to be in the future (or rather, who I plan or design to be) facilitates more than simple self-cognition and self-understanding at a given moment in one's life. It is also a projection into the future: what identity am I building, for which elements offered by the cultural context and my relations with "Others" do I reach, which of these elements enriches the sense of my living, and which of them helps me understand that

11 The conception of a rapid, artificially formulated sociocultural narrative for the new state was accompanied by the idea of rebirth. Key in this was the introduction of Modern Hebrew into general usage as the nucleus also of the new construct which was to be "Israeli culture" - a unifying element for the Israeli Jewish nation. The ideological battle for the "Hebrewization" of any and all linguistic phenomena did, on the one hand, achieve success in the form of a "created," new (in a sense) language and the emergence of Modern Hebrew literature. On the other hand, however, the negative effects are felt to this day: this sociocultural concept "excludes" all non-Hebrew linguistic circles, is decisively inauspicious for Israeli authors who write in other languages, and does not permit them to join Israeli literary milieus.

12 See Cornea 2012; Chiper 2015; Cristea-Enache 2009; Mudure 2014.

13 See Ricœur 2005; Ricœur 1992. 
sense? The narrative approach to the issue of identity permits better comprehension and, by way of "interpretation," a way to understand oneself amidst this changeability.

In the texts of Virgil Duda, on more than one occasion, elements can be found which justify the soundness of Ricœur's theory of narrative identity and Welsch's concept of transculturalism. Worth considering here would be, for instance, recollections of his father by Duda in the first book he penned in Israel, România: Sfîrșit de decembrie. ${ }^{14}$ Faced with social problems (seemingly small problems in a small community), the main character and his pertinent ethical-moral choices veer far from any monolithic ethnic or cultural determinism. The reminiscences are those of a simple man who,

a trăit întreaga lui prea scurtă viaţă, într-un mediu evreiesc, cu fraţi, prieteni și camarazi [...] asemenea lui. [...] Avea atîta dispreţ [...], ură împotriva naţionalismului de orice fel, încît se socotea dator să refuze și formele obtuze ale naţionalismului evreiesc. Ce ţie nu-ţi place, altuia nu-i face. [...] Tata era un om 'liber', care visa să nu se supună orbește, să nu se teamă de alţii [...], se străduia, oricît de greu îi era, să-și păstreze bruma de independenţă, [...] să privească lumea fără (cu cît mai puţine) prejudecăţi, [...] pe scurt: să fie cît mai om cu putinţă. Așa interpreta el povestea lui 'trăim o singură dată'. ${ }^{15}$

Virgil Duda recounts a family tale from his childhood wherein his eldest brother, attending a Jewish religious school, did not (due to the opportunism of a teacher) receive an honor he had earned for good marks in his studies. The award was conferred upon the less bright son of the local "rich man." This injustice inflicted by one's own turned out to be far worse than the wartime suffering inflicted by "Others." Therefore the father decided (over the mother's objections) to send his younger son to a public, non-Jewish school. The lack of anti-Semitic reactions on the part of his classmates in this school (even during "their" religious lessons), and this example of his father's ethical principles was - as the author admits - a significant element in the shaping of his later attitudes: "Momentul a fost decisiv pentru formaţia spirituală. Oricîtă încredere aş fi avut în tata și în opiniile lui, dacă aș fi trăit atunci antisemitismul, cred că rămîneam marcat pe viaţă."’16

In time, Rubin Leibovici became (albeit not severing ties to his Jewish roots) Virgil Duda - an open individual, a Romanian writer, and a conscious, self-appointed participant in Romanian culture. It is rather evident that the most crucial cultural component for the writer - his homeland, so to speak - was his language, his medium of expression. For Virgil Duda that language was and continues to be (even now after nearly three decades

14 Completely different from all his previous works, this is neither a novel, nor a collection of short stories, but rather a reflection, memoir, and justification for his decision to leave Romania (Duda 1991). It should be noted that - due to space restrictions as well as a specialized focus - Duda's pre-emigration works are deliberately omitted herein, and thus the lack of references to key bibliographic items from his pre-Israel period.

15 "[He] spent the whole of his too brief life in a Jewish milieu, with his brothers, friends, and acquaintances mostly like him [...]. He had so much contempt $[\ldots]$ and hatred towards all manner of nationalism that he considered it his responsibility to also reject the primitive forms of Jewish nationalism. Do unto others as you would have them do unto you. Papa was a 'free' person who dreamed of never surrendering blindly, never fearing others $[\ldots]$, and looking at the world without superstitions (or at least with as few as possible) - in other words, he was as much a human being as possible. This was his interpretation of the saying 'We live but once"" (Duda 1991: 64-66).

16 "That was the decisive moment in my spiritual formation. Regardless of the great trust I had in my father and his opinions, I believe that if I had met with any sort of an anti-Semitic reaction then, it would have marked me for life" (Duda 1991: 70). 
of life in Israel) the Romanian tongue. It is only in this vernacular that he is able to express himself because it is only in this language that his narration is conducted. Inscribed only in Romanian are all the elements of the cultural codes which the writer selected to tell the tale of his life, which he internalized, and which comprise the axis of his identity.

Conversezi cu vecinii, colegii, vânzătorii, călătorii din autobuz, funcţionarii de la primărie etc. în ebraică, asculţi din oră în oră buletinele de știri, urmărești încordat telejurnalele de seară, la diverse posturi interne sau externe, apoi te așezi în faţa computerului având în minte numai şi numai personajele și situaţiile tale "românești."17

This is how, in a conversation with Daniel Cristea-Enache, Duda expresses the functional roles of languages in Israel - each tongue fulfilling a different function. Less due to its communicative usefulness and functionality as a tool of his trade, and more out of a nostalgia for a lost fatherland, ${ }^{18}$ this problem of being bound to the Romanian language comes into view rather often in his texts - interwoven in places, found between the lines uttered by the characters of his stories.

A consequence of this clinging to Romanian in his literary works is, on the one hand, an absence in Israeli culture, but, on the other hand, a presence on the Romanian publishing market. Every one of Virgil Duda's books has been published in Romania (by such prestigious presses as Polirom or Hasefer); none has been published in Israel. None, too, has been translated into Hebrew even if critics affirm that this is literature of a very high level. ${ }^{19}$ Indeed, Virgil Duda's compatriot - a Romanian émigré writer of Jewish descent and of the same generation - Norman Manea also much appreciates the prose of his peer (Safirman, Volovici 2007: 318-322). Manea also emigrated in the second half of the 1980s - but to the USA instead of Israel and is thus perceived as a "real" emigrant. As such, he is successful, well-known, and translated into many languages, including (as luck would have it) Hebrew.

One could venture an opinion that the Israeli political discourse described earlier herein - channeled as it is towards the shaping of a sociocultural monolith - turned out to be an experiment one of whose victims was Virgil Duda, a Romanian writer-Israeli writer who did not achieve success in his new (chosen by necessity) country. Even so, this new homeland has become a valuable source (in Jullien's understanding of the term) from which the writer draws elements which enrich his identity. Moving from one cultural spectrum to another, and from one geographical and social space to another is not a phenomenon without its dramatic turns.

The first act of egress beyond his familiar terrain (the Jewish shtetl) takes place by way of his father's decision:

17 "You talk to neighbors, friends, shopkeepers, fellow passengers on a bus, clerks from the city hall, etc. in Hebrew. You follow the evening news on television, on different channels, national or foreign. And then you sit down in front of the computer and your head is full of nothing but your 'Romanian' characters and situations" (Cristea-Enache 2008).

18 Here understood as the Romanian cultural space and not as the nation-state of Romania.

19 Valeriu Cristea, Mircea Iorgulescu, Gabriel Dimisianu, Daniel Cristea-Enache, Bianca Burța-Cernat, Zigu Ornea, and Leon Volovici are but a few of the Romanian literary critics who have highly regarded the works of Virgil Duda. 
Am trecut astfel, de pe ulița noastră (un amestec de români, evrei - majoritari - greci, ruși), dincolo de pod (la propriu și la figurat), într-o zonă preponderent (exclusiv?) românească și, pentru mine, necunoscută. Prima oară 'în viață' treceam granița naturală, pe podul de lemn [...]. Cu un an înainte, la grădinița de copii [...] mă aflasem pe ultimul bastion dinaintea podului, de pe meterezele căruia se ghicea lumea de dincolo. ${ }^{20}$

Noteworthy is that the small, private homeland of early childhood was neither culturally nor ethnically homogenous which - in accord with a psychological conceptualization of identity - would have to influence the shaping of the writer's identification. Depictions of that multicultural world appear in Duda's texts not only descriptively but also in ambiguous constructs or borderline characters (such as his childhood friend, Raul Siropol, one of the heroes of Un cetățean al lumii).

The second transgression, this time more geographical, is an effect of the writer's own decision. It was his choice, but certainly determined by external circumstances the dramatic situation of Romania under Ceaușescu: “[ ...] o dictatură cum n-a mai fost nicăieri." ${ }^{21}$ An imposed reality (as in the case of subjection and servitude) deforms selfperception in its crooked mirror. And when the individual narrative (in Ricœur's sense) clashes with a surfeit of intolerable elements, then the only solution is to radically and drastically reject them by moving away. Such was the case of Virgil Duda who, realizing that "Mi s-a furat patria. Cumplit," 22 undertook the risk of abandoning the entire territory (literally and figuratively) of Romania. The consequences of this were, for him (especially as a writer), extremely acute. In an interview from 2015, the artist dubbed this decision to emigrate a conscious form of suicide: "Sînt un evreu, născut într-un tîrg din Moldova, hotărît, pînă la vîrsta de 'patruzeci și ceva' să trăiesc și să mor în România, precum au făcut strămoșii mei de cîteva sute de ani încoace. Și să scriu literatură. Am ajuns, totuşi, acum 'la spartul tîrgului', să locuiesc la Ierusalim, ca pelerin al nici uneia dintre cele trei mari religii ale lumii." ${ }^{23}$ In the story Despărţirea de Ierusalim, through the narrator, Aurel Abramovici, the author reflects upon his first tangible encounter with the new space, adaptations, and the emigrant's dilemmas, calling to mind this issue of the decision to emigrate (Duda 2005).

The modal nature of Virgil Duda's transversal mind ${ }^{24}$ facilitates (it seems) his ingress into a new context and, more importantly, inclines him to draw again from yet another source. Ultimele iubiri, a novel published by Polirom in 2008, is "Israeli." It is still full of Romanian associations in the construction of the heroes' biographies and their reminiscences, as well as in the reconstructing of their intertwined fates, in illo tempore, in

20 "And thus I walked out of our street (a mix of Romanians, Jews who were the majority, Greeks, and Russians), across the bridge (in a literal and figurative sense) into the main area which was (solely?) Romanian and, for me, unknown. For the first time 'in my life' I crossed this natural boundary along that wooden bridge [...]. A year earlier, in preschool [...] I found myself at the last bastion before that bridge beyond which border loomed this world on the other side" (Duda 1991: 69).

21 "A dictatorship such as has never been met before" (Duda 1991: 54).

22 "My fatherland has been stolen from me. Cruelly and utterly" (Duda 1991: 30).

23 "I was a Jew from a small town in Moldavia, unequivocally, until the age of 'forty-some years'. To live and die in Romania, just as my forefathers had done for hundreds of years. And to write literature. But now, cut off from my roots, I am living in Jerusalem like a pilgrim who does not identify with any of the three great religions of the world" (Duda 1991: 65).

24 "The transversal mind strives, above all, for the most coherent analysis and reconstruction of individual paradigms" (Welsch 1998: 22). 
Romania. Yet it is also strongly grounded in the picturesquely described (via the masterful meticulousness of a careful observer) ${ }^{25}$ topographical space of Tel Aviv and the social space of its inhabitants. Duda presents in this story an entire spectrum of milieus (including those of the social margins) - the microcosms and demimondes of this metropolitan community - in a way that leaves no doubt as to the author's insight and familiarity.

Moreover, through the literary discussions and statements of the characters, the author expresses his own views and opinions (both positive and critical) regarding this chosen land. On the one hand, we read: "Urăsc această ţară blestemată!" 26 and "Ţara cea mai birocratică din lume. [...] tîrgul proștilor la nivel naţional." ${ }^{27}$ On the other hand, however, we discover passages in which positive elements of democracy are noted, such as care for the marginalized, the existence of all manner of organizations, and an entire system of social welfare (Duda 2008: 484-486). A multitude of similar references to elements from both his old and new spaces can be found in nearly every book from Duda's Israeli period. The positive and negative accents are scattered on both sides as the author remains an observer as if suspended in two worlds.

Nonetheless, his distance vis-à-vis strictly religious phenomena and religious representatives remains constant: "[...] am constatat că primul turist din acest loc necunoscut s-a nimerit să fie un evreu ultrareligios, în negru de la pălărie pînă la pantofi. [...] am trecut pe lîngă conaționalul în continuare nemișcat și mai străin-ca-străinii, cum îl consideram [...]." ${ }^{.28}$ Virgil Duda appears to have belonged to a secular, lay world throughout his life heretofore. At the same time, he is an astute participant-observer of Israeli political practices. Another source of his interests is, indubitably, the uncertainty of his existence in this new homeland, despite a concurrent and ever stronger attachment to it. Each volume by Leibovici reveals an evolution of familiarization with the new geographicalcultural space; the author unambiguously expresses this in a moving fragment found in ponderings by the hero of Viața cu efect intârziat (Duda 1999: 226-227). A constant is the writer's sharpened sensitivity to language. Hebrew is no longer a completely foreign tongue, but Romanian remains his homeland. A friend of Rubin Leibovici's was not inaccurate when, during a ceremony to confer upon Duda the Bucharest Writers Association award for Șase femei (Duda 2002).

Costel Safirman commented that, "Limba este singura patrie a scriitorului." ${ }^{29}$ And that is why the literary characters of Virgil Duda's novels always react at the unexpected sound of their home tongue in a foreign space (Duda 2011: 33).

Interesting from the point of view of identity construction is the way Duda builds his characters, forcing his reader to extract their traits; he does not serve up descriptions but portrays his actors in action on the Tel Aviv stage. It is only through their behavior here and now that the author permits a reconstruction of their identities - on the basis of their

25 Alexandru Mirodan wrote that "înainte de toate Duda este o privire" ["With Duda it is, above all, the gaze"] (Mirodan 1997: 180).

26 "I hate this damned country" (Duda 2008: 461).

27 "The most bureaucratic country in the world. A festival of idiots on a national level" (Duda 2008: 514).

28 "I noticed that the first tourist encountered in this foreign place [Cyprus] was an ultraorthodox Jew, dressed all in black from his hat to his shoes. [...] I passed by my still unmoving compatriot who seemed more alien to me than any foreign visitors" (Duda 2011: 12-13).

29 "Language is the only homeland of this writer" (Safirman, Volovici 2007: 336). 
fates, their reminiscences from Romanian times, and their choices made over the course of a lifetime. This would seem to be an intentional technique.

Reading Duda's Israeli-period prose, one could venture a claim that the writer testifies to fundamental principles underpinning the complementary theories of identity (Ricœur) and cultural identity (Welsch). His texts clearly convey the author's need to heed the command, "Cunoaște-te pe tine însuţi" ${ }^{30}$ - to delineate one's identity and its constitutive traits. Identity is shaped and formed through actions as well as through narrations of select cultural elements. It is not determined a priori by national affiliation, but by the context of an individual life and the more or less arbitrary choices made as a part of it; this always happens vis-à-vis the "Other" because it is in this relationship that the process of auto-identification transpires. A lifestyle and decisions made point the way to how an individual describes him or herself and how others describe him or her (Torzewski 2014: 73-84).

Each in fact cultural space is of a hybrid nature, ${ }^{31}$ composed of a network of varied elements which enrich, broaden horizons, and underpin the formation of an open yet solidly grounded ethical-moral self-identification. It would not be an exaggeration to state that Virgil Duda-Rubin Leibovici represents something of a hypostasis for the contemporary model of a desirable identity: complicated, diverse, and, therefore, open. Is Virgil Duda a citizen of the world? If so, then he is a citizen with a solid narrative of his own which is continually being created; it is both changeable and constant in its fundamental characteristics. It appears that the principal pillars around which the writer's life story is spun are a curiosity about the world (or worlds) and people (those completely different and those very similar) as well as an openness towards the world (those worlds) and that "Other" (those "Others").

By way of a conclusion, it would be worth recounting a short family story which the writer told me in the course of our talk in 2015. In conversation with his grandson during a visit to the United States, at the home of one of his daughters, Rubin Leibovici had posed an ostensibly simple question: Who are you? Who are you if your grandfather is a Romanian Jew, your grandmother a Hungarian Christian, and your father a Turkish Muslim? Not wavering for a second, the youngster retorted that he is an American. The visible pride with which Virgil Duda told this tale - pride in his grandson's full self-confidence and obvious self-assuredness - expresses the crux of Rubin Leibovici's identity and the ideas he has for its projection into the future. ${ }^{32}$

30 "Know thyself," the Delphic maxim found inscribed on the Apollonian temple, is something of a leitmotif in Duda's Un cetățean al lumii. Its title, "Citizen of the world" is repeated countlessly as a reference point in reflections on the meanderings and complicated identities of the characters in this novel.

31 It would be difficult to ignore a strong rooting in the broadly understood cultural space of not only Europe, but one could say of the whole world. This Duda exemplifies in his works without dazzling erudition. As Bianca Burța-Cernat wrote of him, "La acest autor livrescul se infiltrează discretși infinit mai insidios în text, topindu-se în pasta ficțiunii. Cititorul 'simte' imediat aluzia la Gogol sau la Thomas Mann, întrevăzînd (în absența oricăror explicitări 'didactice') întreaga rețea de tensiuni livrești ascunsă [...].” [“In this author, erudition penetrates discretely and much more insidiously with respect to the text, dissolving into the content of the fiction. The reader immediately 'senses' the allusion to Gogol or Thomas Mann, perceiving (in the absence of any 'didactic' elucidations) a hidden network of literary references.'] (Burţa-Cernat 2008: 12).

32 This article was written in July of 2017; it was but a mere two months later that Virgil Duda passed away in Tel Aviv. 
BIBLIOGRAPHY

ANDERson Benedict, 2002, L'imaginaire national, Paris: La Découverte.

Bauman Zygmunt, 2000, Globalizacja, Warszawa: PIW.

Bauman Zygmunt, 2007, Tożsamość. Rozmowy z Benedetto Vecchim, Gdańsk: GWP.

BaUman Zygmunt, 2009, Sztuka życia, Kraków: Wydawnictwo Literackie.

BнaвHa Homi K., 2010, Miejsca kultury, Kraków: WUJ.

BrZEZIŃSKA Anna, 2006, Dzieciństwo i dorastanie: korzenie tożsamości osobistej i społecznej, (in:) Anna BrzezińSKa, Aleksandra HulewsKa, Justyna SŁomsKa (red.), Edukacja regionalna, Warszawa: PWN.

Burța-Cernat Bianca, 2008, Între două lumi, (in:) Observator cultural, nr 449, 13-19.11.

Chiper Sorina, 2015, Globalization and its (Dis)Contents in Virgil Duda's Un cetăţean al lumii (A Citizen of The World), (in:) www.upm.ro/2/GIDNI-02/LIT\%2002\%20E9.pdf (access: 4.01.2017).

CoRnea Paul, 2012, Legături fără frontiere, Revista 22, 10.01.

Cristea-Enache Daniel, 2008, Nu mai sîntem tineri, (in:) România literară, nr 45.

Cristea-Enache Daniel, Virgil Duda in dialog cu Daniel Cristea-Enache, Cultura, nr 245 z 15.10.2009.

Duda Virgil, 1991, România. Sfârșit de decembrie, București: Hasefer.

Duda Virgil, 1999, Viața cu efect întârziat, București: Hasefer.

Duda Virgil, 2002, Șase femei, București: Hasefer.

Duda Virgil, 2005, Despărțirea de Ierusalim, București: Hasefer.

Duda Virgil, 2008, Ultimele iubiri, Iași: Polirom.

Duda Virgil, 2011, Un cetățean al lumii, Iași: Polirom.

HalBWACHs Maurice, 2008, Społeczne ramy pamięci, Warszawa: PWN.

Hoвsваwм Eric, 2014, Nations et nationalisme depuis 1780, Paris: Gallimard.

Holban Ioan, 2014, Scriitori israelieni de limbă română, Iași: Editura 24 Ore SRL.

JulLien François, 2016, Il n'y a pas d'identité culturelle, Paris: L'Herne.

KARCZYŃsKa Eliza, 2014, Odkrywanie siebie w narracji. Koncepcja tożsamości narracyjnej w myśli Paula Ricœura i Charlesa Taylora, Humaniora. Czasopismo Internetowe, nr 1 (5), pp. 65-76.

Kaufmann Jean-Claude, 2013, Kiedy Ja jest innym, Warszawa: Oficyna Naukowa, p. 22.

Mirodan Alexandru, 1997, Dicționar neconvențional al scriitorilor evrei de limbă română, vol. II, Tel Aviv.

Mudure Michaela, 2014, Virgil Duda and the Jewish-Romanian Identity in the Mediterranean World, (in:) A. RADu, Constructions of Identity VII., ed. Cluj-Napoca: http://real.mtak.hu/22476/1/Constructions_of_Identity_VII_u_091138.409662.pdf (access: 17.12.2016).

PopPer Karl, $200 \overline{6}$, Spoteczeństwo otwarte i jego wrogowie, vol. I, Warszawa: PWN.

Riceeur Paul, 1992, Filozofia osoby, Kraków: WN PAT.

Riceeur Paul, 2005, O sobie samym jako innym, Warszawa: PWN.

SAfirman Costel, Volovici Leon, 2007, Noi întâlniri la Ierusalim, București: ICR.

Smith Anthony D., 2007, Nacjonalizm, Warszawa: Wydawnictwo Sic!

SмIтн Anthony D., 2009, Etniczne źródta narodów, Kraków: WUJ.

Torzewski Wojciech, 2014, Etyczne znaczenie koncepcji tożsamości narracyjnej a świadomość dziejowości, Filo-Sofija, nr 25 (2), 73-84.

URIAN Tudorel, 2007, Memorie și cultură, România Literară, nr 20 (25.05-31.05).

Welsch Wolfgang, 1998, Transkulturowość. Nowa koncepcja kultury, (in:) Roman KuBICKI, Filozoficzne konteksty rozumu transwersalnego. Wokót koncepcji Wolfganga Welscha, part 2, Poznań: WN UAM. 